Original Research Paper

\title{
Analysis of Validation Development of Learning Media of Microscope Digital Portable Auto Design to Improve Student Creativity and Problem-Solving Ability
}

\author{
Adi Hardiyansyah ${ }^{1 *}$, Aris Doyan ${ }^{1,2}$, A. Wahab Jufri, ${ }^{1,3}$, Susilawati ${ }^{1,2}$, Jamaluddin ${ }^{1,3}$ \\ ${ }^{1}$ Master of Science Education Program, Mataram University, Indonesia \\ ${ }^{2}$ Physic education Program, Mataram University, Indonesia \\ ${ }^{3}$ Biology Education Program, Mataram University, Indonesia
}

Article history

Received: May 20 th 2019

Revised: July $15^{\text {th }} 2019$

Accepted: July $18^{\text {th }} 2019$

*Adi Hardiyansyah: Master of Science Education Program, Mataram

University, Indonesia;

Email:

adihardiyansyah1991@gmail.com

\begin{abstract}
This study aims to produce a valid product in the form of learning media of a microscope digital portable auto design, using the Dick and Carey development model. Media portable digital microscope learning auto design was developed to enhance the scientific creativity and problem-solving abilities of students in light material and optical devices. However, at this writing focused on the process of validation testing through validation tests on the development of learning media. The final result of this research is to produce a learning media development product in the form of a valid portable digital design microscope. Based on the results of the validation test by 3 material experts and the validity media, the media were at an average of $97.78 \%$ with very good criteria.
\end{abstract}

Keywords: Learning Media; Microscope Digital Portable; Problem-Solving

\section{Introduction}

Learning is a form of student interaction, both with teachers, between students, the environment, and learning media. The learning process in educational units is held interactively, inspiring, fun, challenging, motivating students to actively participate, and providing sufficient space for initiatives, creativity, and independence in accordance with the talents, interests and physical and psychological development of students. For this reason, each education unit conducts learning planning, implementation of learning and assessment of learning to improve the efficiency and effectiveness of graduate competency achievement (Permendikbud No. 22 of 2016).

Education in Indonesia that we meet today is a cause for concern. Education in Indonesia is still relatively low and has not succeeded optimally, especially for science learning. Indications of the still low learning outcomes of science in Indonesia can be seen from the acquisition of national exam (UN) average scores for junior high school/MTs each year, which scores are relatively low. The same is true for the province of West Nusa Tenggara, data obtained from the Education
Assessment Center (Puspendik) as seen in the following screenshot.

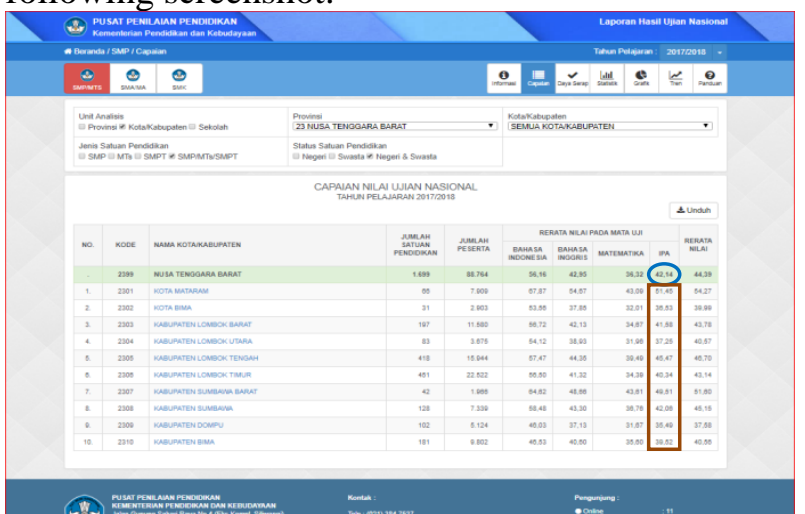

Figure 1: Achievement of the NTB Province National Examination Value in 2018

The low achievement is influenced by several factors, among the problems are media and scenarios that are less innovative in the learning process, in which means that the teaching-learning process is generally based on the material (content based). In the learning process, students are not encouraged to develop thinking skills. The learning process in the classroom is directed at the child's ability to memorize information. The child's brain is forced to understand the information he remembers to connect it to everyday life. To produce a superior human figure is needed a form 
of education that can improve the ability of students in the basic things.

Based on the results of the pre-research survey, conducted on Putra Mataram Middle School students, it was found that there was a tendency for students who considered science subjects to be difficult and considered abstract and also the lack of learning media and practical tools available at school.

Previous research has proven that learning media can improve the quality of students' thinking. Learning abstract physics concepts tends to be difficult for teachers, so generally the results of physics learning in abstract material are lower than in concrete material. One alternative that can be used to support learning abstract concepts namely the use of computer technology in learning (Jumuri, et al., 2015) and Gagne in Siagian \& Tanjung (2012) states that media are various types of components in the student environment that can stimulate the ability to think to learn. While Briggs in Siagian \& Tanjung (2012) argues that all physical tools that can present messages and stimulate students to learn.

The above description states that one of the supporting factors of education is the availability of learning media. According to Sitompul \& Astuti (2012) that learning media can function: (1) overcoming the limitations of experience possessed by students, (2) going beyond the limits of classrooms, (3) allowing direct interaction between students and their environment, (4) producing uniformity observations, (5) instill true, concrete and realistic basic concepts, (6) generate new desires or interests, (7) generate motivation and stimulate children to learn, and (8) provide comprehensive experiences from concrete to abstract.

Dale in Davis \& Summers (2015) said: "one's learning outcomes are obtained through direct experience (concrete), the reality that exists in one's living environment than through artificial objects, to verbal symbols (abstract). Increasingly to the top of the cone, the more abstract the message media is.

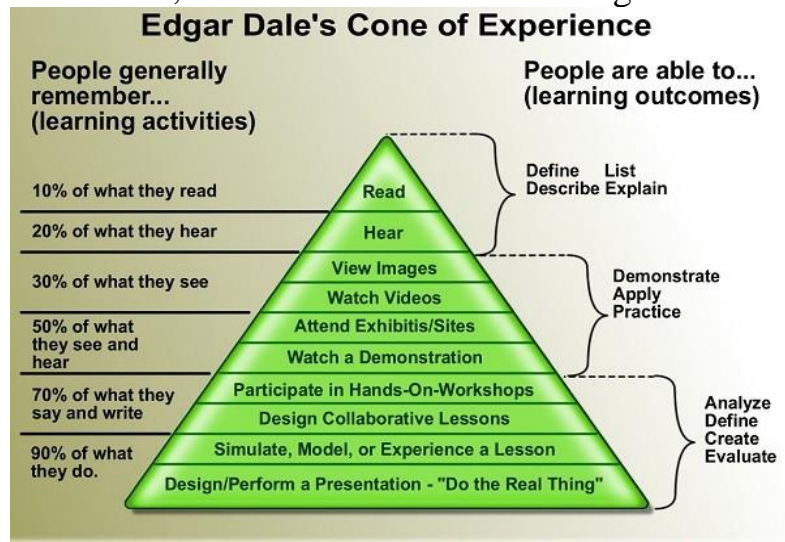

Figure 2: Krucut Dale
The process of learning and teaching interaction does not have to be from direct experience but begins with the type of experience that best fits the needs and abilities of the group of students faced by considering the learning situation. Direct experience will provide information and ideas contained in that experience, because it involves the senses of sight, hearing, feeling, smell, and touch. Dale believes that abstract symbols and ideas can be more easily understood and absorbed when given in the form of concrete experiences.

From the description above, the researchers wanted to develop a portable auto digital microscope learning media. The main purpose of the development of this media is to improve students' problem-solving skills and creativity in light and optical instruments at the VIII grade junior high school level. The next goal is to facilitate the instructor in teaching sub microscope material on the subject of light and optical devices.

Doyan \& Sukmantara (2014) explain that problem-solving ability is the ability of students to use knowledge and concepts that are understood to solve problems in everyday life. The creativity is the ability of an individual to produce new ideas, whether in the form of real work or a combination of something that exists to produce something new (Pukdeewut et al., 2013).

Based on the description above, researchers are interested in developing portable digital microscope learning media to improve the ability to solve problems and creativity of junior high school students in light material and optical devices.

\section{Method}

This research is development research that will develop learning media in the form of a portable auto digital microscope developed with the Dick and Carey (2001) development model. This model was developed based on the learning perspective of behaviorism, cognition, and constructivism to present subject matter (Chang, et al., 2017). This development model includes the following stages: (1) Formulating Specific Learning Objectives; (2) Learner and Context Analysis; (3) Instructional Analysis; (4) Identification of Learning Objectives; (5) Developing tools or instruments; (6) Developing Learning Strategie0s; (7) Use of teaching materials; (8) Design and implement formative evaluations; (9) Revise the draft learning program; (10) Design and develop summative evaluations (Pribadi, 2009).

The initial product developed in this study was a microscope portable digital auto design other devices to support learning. Such as syllabus, 
Rencana Pelaksanaan Pembelajaran, Lembar Kerja Peserta Didi, instruments for evaluating students' problem-solving abilities and creativity. Data validity was obtained from the validation of three competent experts. The validation results are analyzed to determine the level of validity and suggestions from experts are used to revise the learning media.

Analysis of the data used in the data obtained from the results of validation by media experts and material experts was analyzed using component percentages based on the Likert scale in Table 1 below.

Table 1: Questionnaire Instrument Scoring

\begin{tabular}{lc}
\hline Answer & Score \\
\hline Very Good & 5 \\
Good & 4 \\
Enough & 3 \\
Less & 2 \\
Very Less & 1 \\
\hline
\end{tabular}

(Source: Sugiyono, 2017)

The score is then calculated to determine the percentage of components with the following equation:

$$
P_{(k)}=\frac{S}{N} \times 100 \%
$$

Information:

$\mathrm{P}_{(\mathrm{k})}=$ Percentage of components

$\mathrm{S}=$ Number of score components of research results

$\mathrm{N}$ = Maximum score.

The percentage that has been obtained is then transformed into intervals as in Table 2.

Table 2: Percentage ranges and qualitative criteria

\begin{tabular}{ll}
\hline Persentase & Kriteria \\
\hline $85 \%-100 \%$ & Very good \\
$69 \%-84 \%$ & Well \\
$53 \%-68 \%$ & Enough \\
$37 \%-52 \%$ & Less \\
$20-36 \%$ & Very less \\
\hline
\end{tabular}

(Source: Sugiyono, 2017)

In this study, if the validator provides a minimum of sufficient value, the product is suitable for use in learning.

\section{Result and Discussion}

Research on the development of learning media of microscope portable digital portable auto design was developed using the Dick and Carey development model starting from the information collection process. Researchers conduct observations in several schools including the Integrated Islamic Middle School (IT) of the
Mataram. Researchers chose the Integrated Islamic Middle School (IT) of the Mataram, Mataram City. Based on the results of interviews with science subject teachers and see the characteristics of students when the learning process takes place. The results of the analysis of students that on average consider science lessons difficult to understand and many calculations. In addition to observations, researchers also conduct literature studies and find out the results of research that is relevant to science material that is abstract in nature. The researchers also found that the learning media used by teachers in schools was still very minimal. Therefore the researcher decided to develop learning media on light material and optical devices based on the characteristics of students and abstract science material in physics.

After conducting instructional analysis, characteristics of students, and mandated in the 2013 curriculum, the researchers developed of learning media of a microscope digital portable auto design. This media will take advantage of technological developments in the form of smartphones that are like the various features in the playstore. This microscope digital portable auto design uses a laser lens that will be combined with a smartphone that is then used to observe objects or insects that are micro-sized, such as the eyes of people's motion flies in the body to fleas and worms, organs in ants and insects such with that. The digital microscope design in question is shown in figure 3 below.

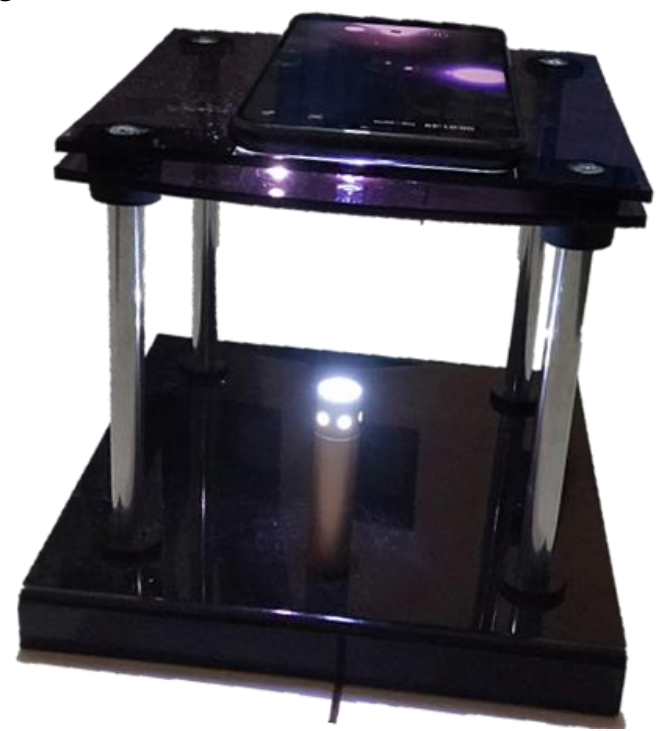

Figure 3: Microscope digital portable auto design

By utilizing the default application from the smartphone, which is then used to connect the media with a computer or LCD projector, this media has added value compared to the media in the school surveyed. These advantages, which make the portable digital auto microscope attractive 
design to be developed. Among the advantages of these media is making observations can be carried out together on a computer screen or LCD screen, besides that the results of observations can be directly perpetuated or published both in the form of images and in the form of videos.

The results of the validation carried out by media experts show good results for this learning media. The experts are lecturers in the Mataram University Natural Sciences education master's program, which number three people. Validation results score of each validator. There are three aspects assessed by media experts, namely, general appearance, special appearance, and media presentation with 15 questions. The results of media expert validation are shown in the form of data analyzed using the percentage of components then taken on average (Table 3), as well as criticism or suggestions from material experts (Table 4).

Table 3. Test Results of Media Experts

\begin{tabular}{llll}
\hline Validator & $\begin{array}{l}\text { Feasibility } \\
\text { Presentation }\end{array}$ & Criteria & $\begin{array}{l}\text { Level of } \\
\text { validity }\end{array}$ \\
\hline Expert 1 & $98,67 \%$ & Very Good & Very Valid \\
Expert 2 & $96,00 \%$ & Very Good & Very Valid \\
Expert 3 & $98,67 \%$ & Very Good & Very Valid \\
\hline
\end{tabular}

Table 4. Results of criticism and suggestions by Media Experts

\begin{tabular}{ll}
\hline Validator & Criticism and suggestion \\
\hline Expert 1 & - Give the name of the tool/media used \\
& - Complete with the usage manual \\
Expert 2 & - Complete with lens enlargement, lens \\
& strength, and lens focus \\
Expert 3 & - Complete with the usage manual \\
& - Complete with the user manual and \\
& $\begin{array}{l}\text { pictures that are given information on } \\
\text { the manual for the use of learning } \\
\end{array}$ \\
& media.
\end{tabular}

From Table 3 above, it shows that the results of trials of portable portable auto microscope microscope learning media experts are very feasible to use. These results can be seen from the average overall score of $85 \%$ with very good criteria. The percentage of feasibility shows that the microscope digital portable auto design learning media is very feasible with revisions according to the advice of media experts presented in table 4 .

These results indicate that learning media are categorized as very feasible to use. The feasibility of learning media developed based on the results of validation by media experts. The validation results show that portable auto disaign digital microscope learning media is very used. The feasibility of the quantum phenomenon learning media developed still needs to be revised according to the advice of experts.

\section{Conclusion}

Based on the description above, it can be concluded that portable auto design digital microscope learning media is very feasible to use with a percentage of $85 \%$ according to experts and a very good category with revisions according to suggestions from media experts.

\section{Refference}

Chang, C. J., Chang, M. H., Liu, C. C., Chiu, B. C., Chiang, S. H F., Wen, C. T., Hwang, F. K., Chao, P. Y., Chen, Y. L., \& Chai, C.S. 2017. An-Analysis of Student Collaborative Problem Solving Activities Mediated by coll Aborative Simulations. Computers and Education. 114(6): 222-235.

Davis, B. J. \& Summers, M. 2015. Applying Dale's Cone of Experience to increase learning and retention: A study of student learning in a foundationalleadershi course. Qscience roceedings (world congress on engineering education 2014).

Dick, W., Carey, L., \& Carey, J. O. 2001. The systemic design of instruction. United state: addison-wesley educational publishers inc.

Doyan, A., \& Sukmantara. I. K. Y. 2014. Pengembangang Web Intranet Fisika Untuk Meningkatkan Penguasaan Konsep dan Kemampuan Pemecahan Masalah Siswa SMK. Jurnal pendidikan Fisika Indonesia 10(2): 117-127.

Jumuri, Kosim, \& Doyan, A. 2015. Pengaruh model pembelajaran kooperatif stad berbasis Multi media interaktif terhadap penguasaan konsep siswa Pada materi termodinamika. Jurnal Penelitian Pendidikan IPA (JPPIPA). 1(1). 123-234.

Permendikbud No. 22 Tahun 2016 tentang Standar Proses Untuk Satuan Pendidikan Dasar dan Menengah.

Pribadi, B. A. 2009. Model Desain Sistem Pembelajaran. Jakarta: Dian Rakyat.

Pukdeewut, S., Chantarasombat, C., \& Satapornwong, P. 2013. Creative Thinking Development Program for Learning Activity Managementof Secondary School Teachers. International Education Studies. 6(12). 8294.

Puspendik. 2018. Capaian Nilai Ujian Nasional Propinsi NTB Tahun 2017-2018. Diakses dari puspendik.kemendikbud.go.id 
Siagian, S. \& Tanjung, P. 2012. Pengaruh Strategi Pembelajaran dan Gaya Belajar Terhadap Hasil Belajar IPA kelas VIII Siswa SMP Negeri 1 Dolok Panribuan. Jurnal Teknologi Pendidikan. 5(2). 193-208.

Sitompul, H. \& Astuti, R. 2012. Pengaruh Media Pembelajaran dan Kecerdasan Ganda Terhadap Hasil Belajar Teknologi Informasi dan Komputer (TIK) Mahasiswa PGSD Universitas Negeri Medan. Jurnal Teknologi Pendidika. 5(2). 180-192.

Sugiyono. 2017. Metode Penelitian dan \& Pengembangan (Research and Development). Yogyakarta: Alfabeta Bandung. 